\title{
Oswald de Andrade's Os condenados and the Decay of the Amazonian Aura
}

SARAH J. TOWNSEND

Pennsylvania State University

\begin{abstract}
This article examines the implications of the Amazonian allusions in the trilogy of novels by Oswald de Andrade now known as Os condenados (originally called Trilogia do exílio). Published between 1922 and 1934, the trilogy revolves around the life and legacy of a young prostitute in São Paulo and is notable for what critics often describe as its cinematic style. My argument picks up on earlier readings that see it as allegorizing the decline of the "aura" of arta process I connect to a shift in the regional dynamics of capital accumulation in Brazil, showing how the aestheticist cult of beauty was associated with the export economy and a mode of uneven development most dramatically exemplified by the Amazonian rubber boom. Ultimately, I gesture toward a reappraisal of the Amazon's role in the imaginary of Brazilian modernismo.
\end{abstract}

Keywords: Brazilian modernism, rubber boom, São Paulo, industrialization, Aesthetics

On February 15, 1922, Oswald de Andrade took the stage of São Paulo's Theatro Municipal and read from a draft of his novel Os condenados (subsequently retitled Alma) during the Semana de Arte Moderna, the foundational event of what would soon be called Brazilian modernismo. ${ }^{1}$ The novel-Oswald's first - tells the tragic tale of a young prostitute in São Paulo and the telegraph

\footnotetext{
${ }^{1}$ Numerous newspaper accounts mention his reading, though none offers an extended commentary or review.
} 
operator-cum-poet who desperately seeks to attain her love. Catcalls and jeers notwithstanding, the book was released a few months later by the publishing house of Monteiro Lobato and presented as the initial installment of a three-part work called Trilogia do exílio. Predictably, one reviewer declared himself appalled by the novel's affront to literary propriety, and while sardonically acknowledging Oswald's "talento no manejar da gíria dos lugares escusos," he indignantly announced that "se nisto é que está o sentimento do belo, se nisto é que reside a arte, abram-se de par em par as portas do meretrício, e sejam às claras as torpezas que lá se fazem, para que se apurem na estética da sentina os prosélitos da arte nova" (Freitas). Others, however, praised the novel for its stylistic innovations and compared its impressionistic technique to the cinema. Monteiro Lobato himself hinted at some reservations about its over-investment in experimentalism but insisted that the fatalistic temperament of the characters was perfectly wrought; referring to the ill-fated child of Alma, the young prostitute, he noted that the life of Luquinhas had been "primorosamente cinematografada" in a series of scenes he compared to the films of D.W. Griffith (69). For his part, Antônio Couto de Barros emphasized that the plot was of little importance. "O que importa, então? Os detalhes... Com espantosa economia de traços, Oswald arma um ambiente, articula seres, derrama vida vermelha sobre a realidade clorótica, de gelatina... O livro inaugura em nosso meio técnica absolutamente nova, imprevista, cinematográfica. Ao leitor é deixado adivinhar o que o romancista não diz, ou não devia dizer" (13).

What is it that the novel does not—or must not—say? One thing reviewers strangely failed to note was that the elusive figure on whom the plot hinges was born in the Amazon. ${ }^{2}$ Allusions to Alma's origins only surface on a few occasions, and the clichéd nature of the plot may partly explain why Oswald's own peers, like subsequent commentators, failed to speculate on the significance of her early life. Nonetheless, the depiction of the characters as exiles in the original title of his trilogy elicits the question: exiles from where, and what? The none-too-subtle religious overtones and descriptions of the Amazon as an Arcadian paradise suggest expulsion from the Garden of Eden, a connection immediately signaled for Latin-literate readers of the first edition by an epigraph

\footnotetext{
${ }^{2}$ One later reader who did take note of Alma's origins is the composer Cláudio Santoro, a native of Manaus, who based his only opera Alma (1985) on the first novel. Alma was staged for the first and only time in 1998 at the Teatro Amazonas in Manaus.
} 
from Genesis about God ejecting Adam from Paradise (Andrade, Trilogia do exílio). But the fiery-haired Alma is not simply a version of Eve, nor is the characters' fall from grace simply an existential condition; the disenchanted realm they inhabit is a real-world city of factory whistles, tramcars, and cabarets peopled by foreign immigrants and transplants from other parts of Brazil. What, then, might it mean that the muse of the Baudelairean telegrapher-poet - himself an "exile" from Recife - hails from the Amazon? Why is it that a portrait of the underside of São Paulo revolves around an Amazonian "soul"?

Indeed, although the poet drowns himself at the end of the novel, Alma returns for a repeat performance. In Estrela de absinto, published in 1927, Alma's new tortured lover is her long-lost cousin, a sculptor recently returned from studying art in Rome; her inability to leave her old lifestyle behind drives him to desperation, but this time it is she who dies, after which he unsuccessfully attempts suicide and then reunites with a former lover only for her to promptly perish as well. Finally, in A escada vermelha, which rounded out the trilogy when it appeared in 1934, the sculptor discovers a non-possessive form of love with a foreign woman referred to as the Mongol, who convinces him to embrace Communism and denounce his bohemian ways, along with religion, art, and what he now recognizes as the "tragédia capitalista de Alma" (284). ${ }^{3}$ Subtle these novels are not, and their melodramatic style — so different from the cutting irony of the author's better-known works - has not held up well against the test of time. Still, all three were acknowledged as important (if imperfect) contributions to modernismo when they first appeared, and the project seems to have held some significance for the author given his commitment to completing it over the course of more than a decade, not to mention his decision to collect the three novels in a single volume in 1941, at which point he retrospectively retitled the first novel Alma and changed the name of the trilogy to Os condenados. As critics have pointed out, autobiographical allusions and references to other modernista artists can be found in all of the texts; though hardly so schematic as a roman à clef, the progressive portraits-of-an-artist and his muses roughly parallel the changing dynamics of modernismo and Oswald's own politicization. But why and how

\footnotetext{
${ }^{3}$ Page references for all three novels refer to the 1978 edition of the collected trilogy Os condenados.
} 
might the capitalist tragedy whose transcendence he charts be tied to the Amazon?

In what follows, I draw out the implications of the Amazonian allusions in Os condenados (originally known as Trilogia do exílio) with an eye to offering a reappraisal of the region's role in the imaginary of Brazilian modernismo. Written almost entirely between 1917 and 1921 (or so Oswald insisted), Os condenados quickly came to be characterized as a transitional series of texts, still bound to a pre-1922 era despite its depiction of a rapidly modernizing city and its fragmented, cinematic style. More recently, Sandro Roberto Maio has argued that both in its plot and in its formal composition, the trilogy allegorizes the decline of the "aura" of art. My own reading of the novels connects this process to a shift in the regional dynamics of capital accumulation in Brazil, showing how the aestheticist cult of beauty was associated with the export economy and a mode of uneven development most dramatically exemplified by the Amazonian rubber boom. The end of the boom and the Amazon's economic decline are the unspoken historical backdrop for Alma's relocation to the industrializing city of São Paulo and her sexual exploitation at the hands of a growing leisure class. Cloaked in religious pathos, a degraded but also idealized object of devotion for artists unable to attain her love, she registers not only the encroaching commodification of art, but also the dependent and uneven nature of Brazil's own economic "progress" - an issue overlooked in critical readings and disavowed by the trilogy itself until the artist's reckoning at the very end.

\section{The Twilight of the Export Age}

Unlike Mário de Andrade, the other central figure of Brazilian modernismo, Oswald de Andrade never ventured into the Amazon. In 1927, when Mário and modernista patroness Olívia Guedes Penteado embarked on a three-month journey up the Amazon River, Oswald was in Paris with his wife, the painter Tarsila do Amaral; the couple sent her teenaged daughter to the Amazon in their stead, though the two groups joined up in Salvador de Bahia on their way back to São Paulo. ${ }^{4}$ This seeming lack of interest in the region is all the more curious

\footnotetext{
${ }^{4}$ Mário de Andrade mentions their reunion in Salvador in his travel journal $O$ turista aprendiz (193-94).
} 
given that Oswald's own mother was from the small port city of Óbidos in the Amazonian state of Pará. The daughter of a landowner who was descended from one of Pará's founding families, Inês Henriqueta de Sousa Andrade was also the sister of José Inglês de Sousa, a prominent politician and writer known for having pioneered naturalism in Brazil with his novels and stories set in the Amazon. Almost all of the family had relocated to São Paulo by the time Oswald was born in 1890, but in his memoirs, he recalls his mother's fantastic stories about her sylvan childhood. Endowed with the spirit of her Portuguese ancestors, he writes, she had learned to swim in the Amazon River, diving below the ships in the dock and scampering to shore when alligators came into sight. Adding a note of color to his own upbringing in the flat, cold environs of São Paulo, she regaled him with "aventuras de sucuris que esmagavam homens bêbados, de onças passeando à noite na folhagem do cacaual, de jacarés defendendo seus ovos, de negros fugidos que voltavam de madrugada para assaltar as senhoras" (Um homem sem profissão 38). Giant snakes and lusty slaves: such was Oswald's infantile imagination of the Amazon.

Since the earliest days of European colonization, the Amazon has been variously cast as a primeval paradise, a lost Eden or El Dorado, and a savage inferno verde. While it is often imagined as lying beyond the bounds of the capitalist world, it has long been a key frontier for the primitive accumulation of resources needed to fuel the expansion of industry elsewhere. During the half century prior to the publication of Os condenados, the region rivaled the state of São Paulo as an epicenter of the boom in exports of primary commodities that coincided with the end of slavery and the passage from the Second Empire to the First Republic. If the south had coffee, the Amazon had the hevea brasiliensis, the most valuable of those trees whose milky sap became known as "white gold." Shoemakers in the United States were using Amazonian rubber by the beginning of the nineteenth century, but the invention of the process of vulcanization in 1845 vastly increased its utility, and in 1867 , the Brazilian government bowed to international pressure and opened the Amazon River to navigation by foreign vessels. Over the next few decades, the region became an object of geopolitical rivalries as multinational corporations based in the United States, Britain, and other European countries vied for dominance in the rubber trade. The port city of Belém, near the mouth of the Amazon, more than doubled in size between 1900 and 1910 (when it counted 190,000 inhabitants) due to the influx of immigrants 
and people from other parts of Brazil (Daou 73). Along with Manaus, which profited from its location near the juncture of the Rio Solimões and the Rio Negro by taxing all exports en route to the Atlantic, Belém was one of the first cities to enjoy electricity and running water; as Ana Maria Daou contends, "as transformações urbanísticas ocorridas, já nos anos 1890, nas capitais das distantes províncias do Pará e do Amazonas anteciparam e estimularam o que viria a acontecer, no início do século, na capital da República" (17). But if the Amazon was at the forefront of "progress," it also illustrated how uneven these gains were: the process of rubber tapping relied on rudimentary methods and a system of debt-peonage in which migrant workers and indigenous captives were forced to purchase over-priced food and goods in exchange for the rubber shipped abroad to make tires and factory machine parts.

These were the contradictions of the Belle Époque — a term commonly used to refer to the urban Amazon and southern cities where the elite lived large on the profits of the coffee boom. In Europe, this was the high point of aestheticism and the doctrine of l'art pour l'art, or "art for art's sake," which found its Brazilian counterparts in the Parnassian poetry later derided by the modernistas, and in the devotion to grand opera. Both Rio de Janeiro and São Paulo had opera houses (inaugurated in 1909 and 1911, respectively), but these were preceded by Belém's Theatro da Paz (1878) and Manaus's Teatro Amazonas (1896). In his wide-ranging world history of the "age of empire," Eric Hobsbawm singles out the Teatro Amazonas as the consummate "cathedral of bourgeois culture" (31) - and indeed it outdid every other opera house in ostentation with its candy pink exterior and incongruous dome tiled in green, yellow, and blue as an homage to the flag of the Brazilian Republic. Like other luxury items, the opera companies that performed on these stages were imported from Europe, but by World War I their numbers had started to decline: as far back as 1876, the explorer Henry Wickham had gathered rubber seeds from the area around Santarém and deposited them at the Royal Botanic Gardens in London, where they were cultivated and then shipped to the British colonies of East Asia to establish plantations that would prove more profitable than wild Amazonian rubber. No longer a prime destination for aspiring entrepreneurs and itinerant workers, the region began to experience deepening poverty and out-migration from rural areas (Browder and Godfrey 62-63). 
Coffee exports would also suffer a jolt during World War I, which interrupted trade and spelled the end of a world-system propped up by British finance. But whereas the Amazon was distant from Rio and historically more connected to Europe than to the rest of the country, São Paulo enjoyed proximity to the capital and political clout - decisive factors in the government's willingness to prop up coffee production and prices with subsidies. ${ }^{5}$ Geographical location, the more settled nature of plantation agriculture, its greater reliance on waged labor, a denser concentration of immigrants, and a more diversified economy were all factors that likely favored the development of small industry in São Paulo, which was presented with new opportunities when goods imported from Europe were no longer available due to the war. Just as growth in the Amazon slowed, São Paulo started to mushroom: between 1910 and 1920, the population grew from 375,00 to 580,000 , and then nearly doubled to reach one million by 1930 . An increasing number of factories - many devoted to textile manufacturing — drew masses of immigrants to the industrial neighborhood of Brás, and major strikes in 1917 and 1919 testified to the contradictions and inequalities created by this growth. By the time construction on the first skyscraper in Brazil (the stillstanding Edifício Martinelli) began in 1922, there was little question that São Paulo had displaced Rio as the most rapidly urbanizing center in Brazil (Font 3334).

The city's rising prominence also set the stage for the emergence of the modernista avant-garde - in a very literal sense, since one of the prime symbols of its newfound wealth was the Theatro Municipal, the opera house where the movement made its official debut. It is well-known that financial backing for the Semana de Arte Moderna came from two scions of the coffee elite: Paulo Prado and Olívia Guedes Penteado, the latter of whom Mário de Andrade would affectionately refer to as "A Rainha do Café" in O turista aprendiz, his journal of his travels through the Amazon and Northeast. In articles leading up to the event as well as speeches given at the Theatro Municipal, however, several of the participants touted their movement as a natural outgrowth of São Paulo's enterprising, industrializing spirit. In an article published two days before the Semana began, Oswald himself recalled his earlier prediction that "São

\footnotetext{
${ }^{5}$ See Weinstein on the federal government's disinclination to fund proposed projects to revitalize the rubber economy (229-32).
} 
Paulo — cidade para todos os futurismos - far-se-ia com certeza o núcleo da reação necessária ao caruncho dos processos acadêmicos de literatura e arte." This event would bear out this claim by showing that "de fato é de São Paulo a gloria de abrigar os primeiros portadores de luz — luz de século forte e construtor" ("O Triunfo" 45). On day two of the festivities, Menotti del Picchia struck a similar chord when he railed against a recent production of Arrigo Boito's Mefistofele staged at the Theatro Municipal by an Italian company. Comparing this imported opera to Parnassianism, he boasted that the artists gathered for the Semana de Arte Moderna would instead create up-to-date art for a modern metropolis where "o industrial de visão aquilina amontoa milhões mais vistoso do que os de Creso" and the aviator Edu Chaves "reproduz com audácia paulista o sonho de Ícaro" (333). If Parnassianism imitated and imported its culture from abroad-along with all the other items Brazil received in exchange for raw materials - the modernistas would contribute to the effort to turn the country into a manufacturer of high-quality goods.

Among the writers who read from their work following Del Picchia's speech was Oswald de Andrade. It is unclear which parts of Os condenados he shared with the audience, but suffice it to say that the text is difficult to reconcile with the art Del Picchia describes, and its depiction of the city is hardly the heroic vision that many modernistas (including the author) proposed in hyping their signature event. In fact, although it was hailed for its originality when it first appeared, the novel now known as Alma almost immediately acquired an outdated air. As early as 1924, Mário de Andrade deemed its novelty a mere matter of "bugigangas sonoras" and declared that only with his new novel Memórias sentimentais de João Miramar had Oswald assimilated the momentum of modernismo at the level of style ("Osvaldo" 27). In an essay from the forties, Antonio Candido echoes earlier commentaries in crediting Os condenados with pioneering the "técnica cinematográfica" in Brazilian literature and regards its most notable aspect as its "culto da forma" and "esforço de fazer estilo" (20). Yet just as Parnassian poetry is prone to accusations of empty formalism, Oswald's technique is exaggerated to the point of becoming "um gongorismo desvairado" (24). Even worse is the "gongorismo psicológico," or the tendency to overaccentuate his characters' traits and rely on banal commonplaces, resulting in an unimaginative congeries of "literatos baudelaireanos, cáftens desalmados, flores 
do vício, velhinhos sofredores, funcionários ridículos"-all the work of a “católico neoparnasiano (21-22). In Candido's view, the trilogy's defects are symptomatic of Oswald's ongoing attachment to the effete world of São Paulo's coffee elite and reveal him to be (at this early stage in his career) a "romancista danunziano pela forma e tradicionalista pela ideologia-reflexo duma personalidade totalmente mergulhada no esteticismo burguês" (25).

That the author's own life experience and inexperience as a novelist are partly to blame for his works' faux pas is surely true. But are the passé elements entirely unintentional and naïve? By the time he wrote Os condenados, in the years prior to the ostensible rupture of 1922, Oswald had long been aware of Italian Futurism and other avant-garde movements - in fact, he and some of his fellow future modernistas were even claiming the "futurist" label. The Baudelairean poet of his first novel, in other words, is clearly a conscious anachronism. As Candido himself stresses, all three of the novels are stylistically out-of-sync with the author's other works: A estrela de absinto came out four years after the more convincingly "modernist" Memórias sentimentais de João Miramar, and although Oswald was editing A escada vermelha up to the moment of its publication in 1934, it still has vestiges of the trilogy's "pre-modernista" origins. Perhaps, then, there is another way to read the anachronistic qualities of these texts; perhaps not only at the level of its plot, but also in its style and form, Os condenados allegorizes the decay of the aura of art - a process that in Brazil was linked to the changing fortunes of an export-dependent economy emblematized by the rise and fall of the Amazon.

\section{Losing the Faith}

For the literary critic of today, schooled in the usual canon of modernist and avant-garde aesthetics, Os condenados almost inevitably calls to mind the writings of Walter Benjamin. For one, there is the Baudelairean poet of the first novel, João do Carmo, who hangs a portrait of his idol above his bed and quotes lines from Les fleurs du mal while wallowing in his angst over the prostitute Alma. In his many essays on Baudelaire, Benjamin sees the French writer as a pivotal figure, not only because he was the last lyric poet to achieve success among a broad European public, but because his verses turn an allegorical gaze on the modernizing cityscape of Paris, vividly conveying the sensorial effects of 
the increasing commodification of literature and everyday life. These effects have to do with the decline of the aura — a phenomenon Benjamin associates with the ritual value of art and other objects of perception, their sense of uniqueness and authenticity, and the impression that although "unapproachable," such objects are endowed with the "ability to look back at us" ("On Some Motifs" 204). One reaction to this loss was the insistence on l'art pour l'art, which reached its apogee in the poésie pure of Mallarmé and what Benjamin refers to in his oft-cited essay on technological reproducibility as a "theology of art" ("The Work of Art" 24). The poetry of Baudelaire, in contrast, opens itself up to the fragmentation, disorientation, and melancholy of capitalist modernity. In the critic's estimation, "he named the price for which the sensation of modernity could be had: the disintegration of the aura in immediate shock experience" "“On Some Motifs" 210). This explains his poetry's affinity with photography, which in reproducing images via technological means debilitates the aura in a process that Benjamin famously argues reaches its revolutionary extreme with film. Here too, then, is another connection to Oswald's trilogy, with its short snippets of action and emotion that critics so often describe as cinematic.

In a recent (and rare) study of Os condenados, Sandro Roberto Maio seizes on the Baudelairean connection in order to read the novels through the lens of Benjamin's analysis of the nineteenth-century poet. According to Maio, the texts stage the struggle to overcome the Parnassian-Symbolist ethos of Brazil's First Republic, which sought to maintain the poet's symbolic role by hitching the fetishism of literary "technique" to the broader societal ideal of "progress." Ironically, the first novel does this by incorporating the figure of Baudelaire — now enshrined in tradition and possessed of its own aura —into the local industrial(izing) landscape and subjecting this to the same allegorical gaze with which Baudelaire had viewed his environs, dismantling in this way the heroic image of the "poeta-símbolo" and creating "imagens fragmentadas, significantes de uma universalidade em ruínas" (25). Through its references to the poet and the Baudelairean vision of the narrative itself, "a personagem referencial presentifica-se: vive ficcionalmente sua própria ficção e a ficção de seu leitor, a escritura condenada" (20).

Maio's emphasis on allegory has the virtue of foregrounding the temporal unevenness that Benjamin recognizes as intrinsic to modernity, and in reading the novels as evidence that the emergence of modernismo was equally uneven, 
he counters the heroic narrative of the movement as an unprecedented rupture with the past. Yet these insights make certain silences in his interpretation all the more puzzling. For one, he has little to say about the particularities of capitalist development in Brazil, or about how capitalism as a global system might have changed in the sixty-year gap between the publication of Les fleurs du mal in 1857 and the historical moment of the trilogy. Even more perplexing is that although commodification figures prominently in his account, Maio makes barely a mention of the woman whose commodified labor-i.e. sex-provides the premise of the plot. On one occasion, he makes a passing reference to the shared Amazonian upbringing of Alma and her cousin, the sculptor Jorge d'Alvelos, noting that their "passado rural" forms a counterpoint to the metropolitan setting of the narrative's own present (34). But the Amazon is not just any rural region, and part of the reason it casts a pall over the urban landscape of the novel is that its rise and precipitous decline drive home the precarity of progress - particularly in a country where economic development still largely depends on the export of primary products and is especially vulnerable to fluctuations in the world market.

Although Maio, like earlier commentators on the first novel, devotes most of his attention to João do Carmo, the poet-telegrapher is not the first character readers encounter. This role belongs to Alma's grandfather Lucas, who in the first short scene - a mere four lines long - is simply introduced as "o velho" and depicted walking with his dog along a side street in the working-class area of Brás. Brief though it may be, this opening tableau is telling. At no point in the novel is industrial labor ever portrayed, and there is no mention of factory workers, though the sound of factory whistles punctuates the daily routine of the characters; with the partial exception of João do Carmo, the world of the narrative belongs to "unproductive" remnants such as "o velho Lucas" and figures such as Alma and her cáften (pimp) Mauro Glade, whose participation in the economy hinges not on the production of concrete things but on the sale of sexual services, or affective labor. The particular pathos surrounding Alma's frail grandfather comes from the fact that this did not always seem to be his fate. Shortly after Alma becomes pregnant with Mauro's child and runs away to live with João do Carmo, her grandfather falls ill; as he lies on his deathbed, delirious and calling for his granddaughter, his memories of the Amazon bleed into the present, and some of the few details readers ever learn about Alma's family history emerge: 
Numa transmutação, a cor verde e doentia fixou-se, ganhou a paisagem larga e escura que se despejava do quarto.

A Amazônia dormia sob um calor de naufrágio. Em redor dele, o rio cantava e a floresta e o vento, povoando o silêncio de fogo.

Havia parado trinta e sete anos à beira da caudal faquirizante, onde nas noites o luar residia, laminando as águas puras dos igarapés. Idália vinha de Belém, ele subira de Goiás.

Alma crescera órfã, numa seminudez de pequena Ariel propícia, pelas matas imóveis e incendiadas. E, como ele, nadava nas madrugadas diluvianas do rio solitário. Jacarés lodosos e sucuris tentaculares vinham no rolo amarelo das águas (55).

Nothing is ever said of Alma's parents or how they died, but here it becomes clear that her sexual exploitation is linked to a story of economic development and decline that spans several generations and ranges across much of the country. A rough reconstruction of the historical timeline places her grandfather's migration to the Amazon from the central state of Goiás sometime in the $1870 \mathrm{~s}$ - not long after the beginning of the rubber boom, though it is unclear how he made his living, and there is no mention of the rubber trade, just as little is said of the factories in Brás and there is no acknowledgement of the coffee economy on which the growth of São Paulo historically hinged. Nor is there any explanation for why he subsequently decided to head south, but he seems to have arrived in São Paulo (with the adolescent Alma in tow) a relatively prosperous man, able to open a china store and buy several small properties he rented out. On another occasion readers learn that after closing his store, he worked as the manager for a firm in the city center; presumably his retirement and the city's changing economy led to his current impoverishment, and over the course of the novel the Companhia de Desenvolvimento repossesses the two remaining small houses that had supplied him with his only source of income.

As Mário da Silva Brito has noted, the old man's evocation of Alma's childhood bears a clear resemblance to Oswald's later account of his mother's memories of the Amazon. Brito convincingly argues that Alma is a composite portrait of Oswald's mother and his young lover Deisi (the "Miss Cíclone" of his 
diary O perfeito cozinheiro das almas deste mundo), whom he hurriedly married shortly before her death as a result of complications from an abortion to end a pregnancy by another man (Brito xxvii-xviii, xxxii). In the nostalgic, halfconscious vision of her grandfather, Alma appears as an untamed child of the forest, likened to the airy sprite of Shakespeare's The Tempest, and the vitality of nature is unsullied by the specter of slavery that seeps into the tall tales of Oswald's mother, or by the allusion to the ships that ferried rubber downriver and returned with imported goods. If for Benjamin, the aura is always associated with a mémoire involuntaire that calls up an "image of the primeval world" ("On Some Motifs" 203), this scene envelops Alma in an Amazonian aura. The reference to sucuris, the giant water snakes native to the Amazon, also foreshadows her later fall and loss of sexual innocence. By the time the novel begins, Alma has been seduced by Mauro, who puts her to work as a high-class prostitute in Penha (an area known for its many churches) where she now pleasures both the traditional and emerging elite - "os vadios da sociedade chique, os velhos vermelhos do São Paulo Clube, os arrivistas comerciais" (21). Despite her multiple attempts throughout the novel to embrace domestic life, her self-defeating love for her abusive pimp and the allure of fast living in the cabarets and garconnières (those "bachelor pads" that Oswald knew all too well) lead her to return to prostitution.

The man who subjects Alma to this "estupro diário" (22) is described as a "filho confuso de confusos dramas da América," the illegitimate son of a grocer in Brás who was raised by a servant (though the woman was also, it is inferred, a prostitute). Mauro Glade was born into a world where everything was for sale and came to the traffic in women's bodies naturally: evoking an earlier history of savage capitalism on the high seas, the narrative notes that "investindo com unhas de atavismos piratas para os mundos coloridos dos dancings, fizera-se macho na meia-tinta embriagada dos prostíbulos" (7). Mauro's strange last name (which is different from his father's) hints at unplaceable yet distinctly foreign origins, and he is likewise characterized by his American shoes and other imported items of apparel he buys for himself, as well as for Alma and the other women from whose bodies he extracts value. On one occasion, when he and Alma spend the night in a furnished room he has rented, she marvels at the array of makeup brushes, combs, cosmetics, creams, perfumes, and beauty utensils. "Nada disso presta—comentou Mauro deitado, em cuecas de seda. — Só há de 
bom artigo alemão. E, durante a Guerra, não vem" (50). Described as a "deus decaído" (7), Mauro shrewdly recognizes that unlike other prostitutes, many of whom are immigrants, Alma "era um caso raro: uma menina de família brasileira, educada para as devotações burguesas dos lares obscuros, e que rolava num esbandalhamento de gritos e surpresas, pela rampa mirífica das prostituições sensacionais" (21-22). Her erstwhile innocence and respectability stoke the prurient desire of her clients, for whom hypocrisy and debasement are part of the pleasure.

João do Carmo knows nothing of these details when he first develops his own unhealthy obsession with Alma. This young, unpublished poet is from the economically marginalized Northeast, and like Alma, he is an orphan: both parents are dead, his sister is in a mental institution, and his brother is a priest, leaving him the only possibility for perpetuating what will otherwise be a "tronco extinto" (12). After a carefree childhood, he was educated at a French-run colégio, and then acquired his job as a telegraph operator at Estação da Luz through a politician up North who owed his family a favor. Estação da Luz, one of São Paulo's most iconic landmarks, was also an important hub of commerce: designed by the English architect Henry Driver and assembled in Glasgow, it was erected in 1901 in the immigrant neighborhood of Bom Retiro, serving as the main gateway through which immigrants and imported goods entered the city from the seaport of Santos and as the point of departure for the majority of coffee exported from the state of São Paulo. Telegraphy was essential in coordinating this movement of commodities and people, and in bringing people and places into instant communication it held out the promise of abolishing geographic and cultural distance and difference; in the novel, however, this promise is proven false, and it instead calls to mind the link Benjamin makes between the loss of the aura and the isolation of "information" from experience ("On Some Motifs" 174). João do Carmo feels alienated and out of place in his new occupation and seeks fulfillment in religion and writing: "No emprego, considerava-se um só, em meio daqueles inexpressivos burgueses de mocidade extinta, sem banhos ao ar livre, sem namoros sonoros. Perambulava confusamente por estéticas e religiões. Compunha versos e tinha receio de mostrá-los" (13). He finds a certain sense of solidarity among a group of poets and artists, though the novel paints an ironic picture of their cosmopolitan claims, describing nocturnal readings in cafés 
where they applaud each other "incondicionalmente" and annoy the sleepy waiters before stumbling into their horse-drawn taxis at dawn (13).

In a discussion of the decades from the 1880s through the 1920s, Flora Süssekind insists that this "pre-modernista" phase should be recognized on its own terms as the period when literature began to grapple with and assimilate techniques characteristic of new technologies even as literature itself attained the status of a profession. Citing Os condenados, she relates its short, discontinuous sentences and scenes to the journalistic writing also practiced by its author as well as the telegraphic messages relayed and received by its protagonist (85-86). But while João do Carmo's occupation might point to the growing interdependence of the "literary" and "technological" realms (and by extension the realm of the commodity), his fatal flaw is his disavowal of the desacralization of literature — and love. Before learning the reason for her rejection of his letters, João do Carmo idealizes Alma as "o apoio poético da sua desgarrada existência" (10); although devastated when his friend Dagoberto Lessa reveals the truth, the besotted poet imagines how happy he would be to have her "só para ele, mesmo assim, prostituída, desmoralizada, vendida à cidade" and desperately convinces himself that "ela não era a debochada que queriam: era santa, santa, santa!" (41). But the narrative itself also emphasizes the duality of Alma's character. She is a doting mother to her son Luquinhas, who is born on Christmas Day, and an embarrassing excess of religious allusions leave little doubt that João do Carmo is the Joseph to her Virgin Mary — at least until the lure of prosperity draws her into the arms of an engineer who takes her and Luquinhas into his home in the neighborhood of Perdizes. Whereas in the poetry of Baudelaire the prostitute often serves as a mirror for the poet's own ambivalence about his entry into the market, Alma throws into relief her poet-lover's failure to gain a foothold in modern culture. Despite her rustic roots, she finds the cabarets and dance halls thrilling; her other male companions make João do Carmo painfully aware of the fact that "seus pais nunca tinham maxixado" (100); and as a woman "conhecida pelo país inteiro" for her sexual charms (or so he feverishly imagines), she gains the mass publicity that his own unpublished verses never will (70).

Still, Alma is far from a one-dimensional symbol of commodification and the mass market, and there is never any doubt that she is a victim of the social and economic forces responsible for the decay of the aura. On multiple occasions the novel makes mention of a small oratory that her grandfather brought from the 
Amazon, which belonged to Alma's parents, and every day he prays before its miniature angels and saints. Yet as the tragedy of his and Alma's lives unfolds, it becomes clear that any ritualistic power the oratory once had is gone. Alma, imagining Mauro in the company of one of her rivals, laments that "mesmo os santos, de pé, no esburacado oratório, não a defendiam. Ela queria só uma coisa, só um milagre — o amor de Mauro, a fidelidade de Mauro" (11). On New Year's Eve, her grandfather waits for her to arrive and pray with him, but she never comes home, and he is left to listen as the factory whistles blow at midnight while the tiny figure of São José looks out "impassível" from his little niche (35). Toward the end, after both Lucas and his namesake Luquinhas have died, Alma goes back to João do Carmo, but all does not go well. An early warning sign comes when they rent a small, two-room apartment where there are two macaws ("duas araras ornamentais e inquietas" (93)). Although araras inhabit many parts of Brazil, the word itself comes from the indigenous Tupi language and is also the name of several Amazonian indigenous groups. But these two birds have been taken out of their natural environs; they serve merely as decorations, and their agitation reflects the two lovers' own dissatisfaction with their poor imitation of bourgeois domesticity. As Alma once again returns to the garconnières, João do Carmo realizes that she is not the woman he thought he loved and begins to suspect that her aura was always his own invention. With the moneylenders lurking in the wings, the macaws issue foreboding shrieks ("as araras decorativas punham gritos finais nos dias morrentes" (103)). At the end of the novel, the members of João do Carmo's swimming club raise their flag at half-mast in his honor on the banks of the Rio Tietê.

On the night of João do Carmo's suicide, Alma - unaware of what has transpired - drifts off to sleep while thinking of her cousin Jorge d'Alvelos, who has just returned after spending a decade in Italy studying art. The conclusion thus conveniently sets up the plot of A estrela de absinto, the second novel in the trilogy. By the time it begins, Alma and Jorge are lovers and she has just broken off her relationship with Mauro - again — to be with Jorge. The prodigal return of the wayward artist and his incestuous union with his cousin holds out the promise of an atavistic renewal of the Amazonian aura. Contrasting Alma with his former lover Mary Beatriz, a proper young Brazilian woman he left behind in Italy, Jorge muses that: 
Alma, no entanto, com os seus vinte e cinco anos augurais, repunha dentro dele a personagem de guignol que dormia, séculos, quem sabe, desde a invasão do grande rio pelos seus avós, que, retirados do bulício dissolvente das civilizações peninsulares, se tinham honrado na conquista de Mazagão em África, e depois varado o Amazonas até as suas cabeceiras de febre. (111)

Once again, the Amazon appears as Brazil's link to a heroic, transcontinental history of conquest and colonization, though a strange silence shrouds the family's activities and there is no explanation for the changing economic conditions that conspired with multiple deaths to precipitate their migration south. Jorge mentally retraces the trip from the small port city where they lived and recalls how his uncle, following his father's death, sought to lure him to the sertão of the state of São Paulo to live on his fazenda, where "ele se incorporaria ao país, sob o céu propício da América. Casar-se-ia, fundaria novas plantações, prosseguindo, a cavalo, às quatro horas, na posse brutal da terra prometida e achada" (112). Instead a government grant allowed him to make the requisite artistic pilgrimage to Europe - though he is now ready to renounce the dream of fame in order to begin again with Alma. This dream is cut short when Alma betrays him with one of her old acquaintances, a charming "malandro de grande cidade" named Artur who is an office worker and member of a Carnaval club (136). Suddenly, Mauro reappears on the scene and physically assaults her, reactivating a septic inflammation in her fallopian tubes that leads to her untimely death.

In the course of his reminiscences, readers learn that Jorge's love of sculpture began with the "bonequinhas de lama" he made as a child while helping out in his grandfather's china and toy store, where (it can be inferred) he learned by imitating some of the objects for sale. Now his studio is in the Palácio das Indústrias, and he is gradually joined by other artists returning from Europe amidst the flurry of artistic activity leading up to the centennial of Brazilian independence in 1922. The Palácio das Indústrias did indeed house work spaces for artists - including the studio of the modernista sculptor Victor Brecheret, whom Brito sees as one of the real-life inspirations for Jorge d'Alvelos (xxiii) _ but the site also bears an obvious symbolic significance: officially inaugurated in 1924 though in use for several years prior, it was designed to host 
expositions of São Paulo's agricultural and manufactured products as a counterpart to similar exhibition halls in London and France. Ensconced in this architectural homage to the union of industry and aesthetics, Jorge devotes himself to creating an ensemble called As Amazonas e o Cavalo-a fictional counterpart, perhaps, to Brecheret's Monumento às Bandeiras, though it displaces the Paulista pioneers and prospectors as patriotic symbols in favor of mythic women warriors whose name recalls a different region of Brazil. When he learns of Alma's infidelities, Jorge destroys the entire set, leaving only a figure titled A fonte da vida that was modeled after Alma. But if she is an embodiment of primitive vitality, Alma is also and again an index of the artist's own attraction to mass culture. Jorge follows her all around São Paulo and realizes that "a cidade toda a conhecia, a caçava com indiscutíveis direitos" (134). He then starts to tail her other lover Artur, whose easy charm and familiarity with the latest fashions “acabou por seduzir o artista" (136). After Alma's death, Jorge shoots himself in his studio but is saved by friends. In the hospital, he improbably discovers the long-lost Mary Beatriz in the next room, but his chance for a marriage with the national bourgeoisie is foiled when she dies (like a proper Romantic heroine) of consumption. Upon his recovery, he learns that the city wants to buy one of his sculptures, and a cathedral is interested in another. His consecration as an artist has finally arrived, and the novel closes with him in a cathedral praying to Godthough the last sound heard is of an old man hawking phlegm.

In 1927, when this novel was published, there were already signs of political and economic instability. By the time A escada vermelha (later retitled A escada) appeared seven years later, the crash on Wall Street had precipitated a crisis of the coffee economy, Getúlio Vargas had taken power in the "Revolution" of 1930 and was three years away from declaring the Estado Novo dictatorship, and Oswald de Andrade had joined the Communist Party. A mere sixty pages long, A escada lays all of its allegorical cards on the table, openly acknowledging for the first time the economic concerns evaded in the previous two novels. By the time it begins, the crisis has hit, and Jorge has awoken to the fact that Brazil remains a "semi-colonial" country. Now acutely aware that the bohemian circles in which he moves are made up of the decadent remains of families whose glory rested on the enslavement and exploitation of others, he sees what lies behind the quasi-religious aura of art: "num pálido assombro, vira, sobre a cabeça dos incensadores macerados, na pompa calculada do culto, pela porta dos sacrários 
aparecer a cabeça lúbrica do deus Capital" (235). Memories of Alma continue to dog him until the penultimate page, but he is convinced to devote his life to the struggle of the proletariat by his new lover, a woman known as the Mongol who in some ways resembles Oswald's wife during this period, Patrícia Galvão. In the final scene, Jorge's definitive break with the "tragédia capitalista de Alma"a tragedy of bourgeois patriarchy, the nation-state, and an auratic understanding of art - comes when a taxi driver helps him escape persecution by the police for his political activities, and they head into the dark night toward an unnamed place that "tem de toda raça. Alemão, Lituano, Preto, Argentino, Indio" (287).

\section{Modernismo’s Amazonian Soul}

In what is unquestionably the most famous novel of Brazilian modernismo, Mário de Andrade's Macunaíma (1928), the eponymous protagonist ventures out of the Amazon jungle to São Paulo in search of his muiraquitã, a sacred amulet that is now in the possession of a man-eating capitalist who is also the mythic giant Piamã. At the end, he returns home with the muiraquitã (though he quickly loses it again), only to find that he is the last of his tribe and the forest no longer holds charm for him. For all its differences with Os condenados, the novel is another tale of how the Amazon has lost its aura, yet even as it spoofs the idea of the region as a magical paradise, it disavows the realities of the rubber boom and a truth that Oswald's trilogy - though less felicitous as "art"-allows readers to glimpse if not fully see at its end. Like the aura of art, the aura of the Amazon has never been a sign of its exteriority to modernity or capital but a symptom of and spur to its incorporation into the global market. Although imagined as the antithesis to an industrializing São Paulo, it is instead a reminder of the unevenness and precarity of this latest phase of development - and in this sense Paulista modernismo can indeed be said to have an Amazonian soul.

\section{Works Cited}

Andrade, Oswald de. "O triunfo de uma revolução." 22 por 22: A Semana de Arte Moderna vista pelos seus contemporâneos, U de São Paulo, 2008, pp. 45-48.

—. Os condenados. Civilização Brasileira, 1978. 
—. Trilogia do exílio: Os condenados. Monteiro Lobato, 1922.

—. Um homem sem profissão: memórias e confissões, vol. 1: 1809-1919 (sob as órdens de mamãe), José Olympio, 1954.

Andrade, Mário de. Macunaíma. Arquivos, 1988.

—. O turista aprendiz. Duas Cidades, 1976.

—. "Osvaldo de Andrade." Revista do Brasil, no. 105, Sept. 1924, pp. 26-33.

—. "Autores e livros." América Brasileira, vol. 2, no. 14, Feb. 1923, p. 60.

Benjamin, Walter. "On Some Motifs in Baudelaire." The Writer of Modern Life: Essays on Charles Baudelaire, edited by Michael W. Jennings, translated by Harry Zohn, Harvard UP, pp. 170-210.

- "The Work of Art in the Age of Its Technological Reproducibility." The Work of Art in the Age of Its Technological Reproducibility and Other Writings on Media, edited by Michael Jennings et al., translated by Edmund Jephcott and Harry Zohn, Harvard UP, 2008, pp. 19-55.

Brito, Mário da Silva. "O aluno de romance Oswald de Andrade." Os condenados, Civilização Brasileira, 1978, pp. xvi-xxviii.

Browder, John O., and Brian J. Godfrey. Rainforest Cities: Urbanization, Development, and Globalization of the Brazilian Amazon. Columbia UP, 1997.

Candido, Antonio. "Estouro e libertação." Brigada ligeira e outros escritos. U Estadual Paulista, 1992, pp. 17-32.

Couto de Barros, Antônio Carlos. "Livros e revistas." Klaxon, October 1922, pp. 13-14.

Daou, Ana Maria. A belle époque amazônica. Jorge Zahar, 2004.

Del Picchia, Menotti. "Arte moderna: a conferência do Dr. Menotti del Picchia no Municipal...." O gedeão do modernismo, 1920-1922, edited by Yoshie Sakiyama Barreirinhas, Civilização Brasileira, 1983, pp. 327-34.

Font, Mauricio A. "City and Countryside in the Onset of Brazilian Industrialization." Studies in Comparative International Development, vol. 27, no. 3, Fall 1992, pp. 26-56.

Freitas, Paulo de. "Os condemnados: São Paulo e seus homens de letras." Folha da Noite, 4 Apr. 1923, p. 2.

Hobsbawm, Eric John. The Age of Empire, 1875-1914. Vintage, 1989.

Lobato, Monteiro. "Oswald de Andrade: Os condemnados, edição de Monteiro Lobato \& Cia., 1922.” Revista do Brasil, Sept. 1922, pp. 68-69. 
Maio, Sandro Roberto. Eros alegórico da melancolia e do progresso: Oswald de Andrade em Os condenados. Alameda, 2013.

Süssekind, Flora. Cinematógrafo de letras: literatura, técnica e modernização no Brasil. Companhia das Letras, 1987.

Weinstein, Barbara. The Amazon Rubber Boom, 1850-1920. Stanford UP, 1983. 